\title{
Myocardial revascularization in the elderly patient - with or without cardiopulmonary bypass?
}

\section{Revascularização do miocárdio no paciente idoso - com ou sem circulação extracorpórea?}

José Carlos Rossini IGLÉZIAS, Artur LOURENÇÃO JR., Luís Alberto de Oliveira DALLAN, Luiz Boro PUIG, Sérgio Almeida de OLIVEIRA

\section{Abstract}

Objective: To verify if there is advantage in myocardial revascularization the elderly without cardiopulmonary bypass $(C P B)$ in relation to the use of the same, being considered the viability of complete myocardial revascularization (MR) and the hospital morbidity and mortality.

Method: We prospectively studied a hundred consecutive, no randomized patients, with age $>=70$ years, submitted to the primary and isolated myocardial revascularization between January and December of 2000. The patients were divided in two groups, $G_{1}-50$ patients operated with $C P B$ and $G_{2}-50$ patients operated without $\mathrm{CPB}$. Univariate testing of variables was performed with chi-squared analysis in the SPSS 10.0 Program and $p$ value less than 0.005 was considered significant.

Results: There was no renal failure or myocardial infarction (MI) in both groups; the incidence of respiratory failure was identical in the two groups $(4 \%)$; two patient of $G 1$ they had Strokes, and 12 presented low output syndrome, occurrences not registered in $G_{2}$. The need of ventilatory support $>24$ hs was not significant between groups. Medium time of hospital stay was 21.8 and 11.7 days respectively (NS) and the survival after 30 days were similar in the two groups. The patients' of $\mathrm{G}_{1}$ eighty percent had more than two approached arteries, against only $48 \%$ of $\mathbf{G}_{2}(\mathbf{p}<\mathbf{0 . 0 0 0 1})$.

Conclusion: Because the largest number of grafts in the patients of $G_{1}$, we can affirm that the use of $C P B$ can provide a larger probability of complete $\mathrm{RM}$.

Descriptors: Myocardial revascularization, aged. Coronary disease, surgery, aged. Extracorporeal circulation, aged.

Instituto do Coração do Hospital das Clínicas, Medical School, São

Paulo University (InCor HC-FMUSP.).

Av. Dr. Enéas de Carvalho Aguiar, 44,

CEP 05403-000 - São Paulo - SP, Brazil

Correspondence address:

Prof. Dr. José Carlos Rossini Iglezias.

Av. Dr Enéas Carvalho de Aguiar, 44, $2^{\circ}$ andar, Bloco II sala 11 - Jd.

América.

São Paulo - SP - CEP: 05403-000.

Phone: (11) 3069-5234 -

Fax: (11) 3069-5014.

E-mail: dcirossini@incor.usp.br

Presented at the 30th National congress of Heart surgery, Goiânia (GO), 3rd to 5th April 2003. 


\section{Resumo}

Objetivo: Verificar se há vantagem em revascularizar o paciente idoso sem Circulação Extracorpórea (CEC) em relação à utilização da mesma, considerando-se a viabilidade de Revascularização do Miocárdio (RM) completa e a morbimortalidade hospitalar.

Método: Estudados prospectivamente 100 pacientes consecutivos, não randomizados, com idade $>=70$ anos, submetidos à revascularização primária e isolada do miocárdio entre janeiro e dezembro de 2000 . Os pacientes foram divididos em dois grupos, $G_{I}-50$ pacientes operados com CEC e $G_{2}$ - 50 pacientes operados sem CEC. Utilizou-se teste de análise univariada $\stackrel{\div 2}{-}$, por meio do programa SPSS 10.0, com nível de significância de $p<0,05$.

Resultados: Não houve ocorrência de insuficiência renal

\section{INTRODUCTION}

The advent of cardiopulmonary bypass (CPB) in 1953 by GIBBON [1] represented a great conquest for humanity, as it enabled the treatment of intra-cavity congenital and acquired cardiac injuries. This conquest added to the improvement in pre-, intra- and post-operative care, new technology and anesthesia care, and undoubtedly contributed to an improvement in the life expectancy of heart disease patients. At the end of the $1950 \mathrm{~s}$, with the introduction by SONES \& SHIRLY [2] of selective coronary angiography, the door opened to the beginning of direct myocardial revascularization surgery (MR). At the start of 1962, EFFLER et al. [3] demonstrated they were capable of correcting severe obstruction of the left coronary artery branch, using the grafting technique developed by SENNING [4]. In 1964, the results of works on coronary artery surgery performed by KOLESOV \& POTASHOV [5] arrived in the West and in 1967 FAVALORO [6] initiated the modern phase of surgical treatment of obstructive coronary insufficiency, by describing the use of autologous saphenous vein grafts. Numerous people started to enjoy the benefits provided by this type of operation, improving their quality of life and life expectancy.

Conventional MR, as it is a highly complex procedure, involves high hospital costs, as well as long hospitalization periods. More recently, the possibility of achieving benefits using conventional MR without the use of CPB have been published both nationally and internationally, starting from the premise of maintaining the advantages and reducing the costs. This has, thus, been praised as the number one choice for the surgical treatment of obstructed coronary disease. This is because fewer alterations to the homeostasis of the organism are attributed to the procedure, there is a ou Infarto Agudo do Miocárdio (IAM) em ambos os grupos; a incidência de insuficiência respiratória foi idêntica nos dois grupos (4\%); dois pacientes do $G_{1}$ tiveram AVC, e 12 apresentaram baixo débito cardíaco, ocorrências não registradas no $G_{2}$. A necessidade de suporte ventilatório $>24$ h não foi significativa entre os grupos. O tempo médio de internação foi 21,8 e 11,7 dias, respectivamente (NS) e a sobrevida após 30 dias foi semelhante nos dois grupos. Oitenta por cento dos pacientes do $G_{1}$ tiveram mais de duas artérias abordadas, contra apenas $48 \%$ do $\mathbf{G}_{2}(p<0,0001)$.

Conclusão: Levando-se em conta apenas o maior número de enxertos nos pacientes do $G_{1}$, podemos afirmar que a utilização da CEC pode proporcionar uma maior probabilidade de RM completa.

Descritores: Revascularização miocárdica, idoso. Coronariopatia, cirurgia, idoso. Circulação extracorpórea, idoso.

reduction in metabolic stress, shorter hospitalizations and comparatively lower costs for the procedure, preserving the benefits given by the method performed with CPB. With the aim of establishing, over the short term, which method is the best (with or without CPB) for elderly MR patients, considering the lowest morbidity, lowest hospital mortality and the viability of complete MR, a clinical research protocol was designed. This was submitted and approved by the Scientific Ethics Committee of Incor.

\section{METHOD}

In the period between January and December 2000, one hundred patients with ages $=70$ years old who were consecutively operated on at the Heart Institute, Incor, were included in the research after being informed of its objective and method and after they had given written consent. Only patients with indications for primary and isolated MR were included. The patients were prospectively distributed in two groups; the first group $\left(\mathrm{G}_{1}\right)$ consisted of 50 patients submitted to MR with CPB and the second group $\left(\mathrm{G}_{2}\right), 50$ patients who underwent off-pump MR.

The two groups were homogeneous in respect to the age, gender, weight, height and body mass index (BMI). In relation to other existent factors both groups were also similar. These factors included diabetes, systemic arterial hypertension, peripheral vascular disease, acute myocardial infarction (AMI), strokes and renal insufficiency (considering serous creatinine levels $>2 \mathrm{mg} \%$ ) and also the number of involved coronary arteries with injuries susceptible to RM. There were significant differences only related to smoking and dyslipidemia, which were slightly greater in $\mathrm{G}_{2}$ (Table 1).

To try to define which of the studied techniques would 
Table 1. Profile of patients submitted to myocardial revascularization with and without cardiopulmonary bypass

\begin{tabular}{|c|c|c|c|}
\hline Parameter & $\mathrm{G}_{1(\mathrm{~N}=50)}$ & $\mathrm{G}_{2(\mathrm{~N}=50)}$ & $\mathrm{p}$-value \\
\hline Age (years) & $75.28 \pm 2.77(70$ to 80$)$ & $75.82 \pm 4.36(70$ to 87$)$ & N.S. \\
\hline \multirow{2}{*}{$\begin{array}{l}\text { male } \\
\text { female }\end{array}$} & 36 & 32 & N.S. \\
\hline & 14 & 18 & N.S. \\
\hline Weight (kg) & $67.36 \pm 10.28(39$ to 86$)$ & $66.47 \pm 10.4(48$ to 89$)$ & N.S. \\
\hline Height (m) & $1.59 \pm 0.10(1.42$ to 1.80$)$ & $1.61 \pm 0.07(1.48$ to 1.83$)$ & N.S. \\
\hline BMI $\left(\mathrm{kg} / \mathrm{m}^{2}\right)$ & $24.56(19.34$ to 26.54$)$ & $21.91(20.71$ to 26.57$)$ & N.S. \\
\hline Diabetes & 14 & 20 & N.S. \\
\hline systemic arterial hypertension & 40 & 34 & N.S. \\
\hline Smokers & 16 & 6 & 0.0283 \\
\hline Dyslipidemia & 32 & 16 & 0.0025 \\
\hline Peripheral vascular disease & 2 & 0 & N.S. \\
\hline Serous creatinine $(>2)$ & 2 & 0 & N.S. \\
\hline acute myocardial infarction & 28 & 28 & N.S. \\
\hline Stroke & 4 & 4 & N.S. \\
\hline Involved arteries $(>2)$ & 18 & 24 & N.S. \\
\hline
\end{tabular}

bring the greatest advantages, the number of grafts performed, the mean number of grafts per patient and varying parameters indicating or not the presence of higher morbidity were analyzed. The following post-operative parameters were also evaluated:

- the existence of strokes in the post-operative period - characterized by any alteration in the motricity, level of awareness or sensitivity;

- AMI characterized by alterations in the electrocardiogram or increase in the enzymatic levels or by alterations in the motility of the ventricular wall evidenced by echocardiography;

- Appearance of renal insufficiency (creatinine $>2.0$ $\mathrm{mg} \%$ ) or worsening compared to the pre-operative level;

- respiratory insufficiency - considered when the patient requires ventilatory support for a period greater than 24 hours.

Data referring to the duration of hospitalization and hospital mortality (the first 30 days after the surgery independent of length of hospital stay). MR was considered complete, in this study, when all the arteries with at least $50 \%$ of occlusion were grafted. The data obtained were submitted to univariate analysis (chi-squared), using the SPSS version 10.0 computer program, with $p$-values $<0.05$ being considered significant.

\section{RESULTS}

The mean number of grafts per patient was similar in the two groups, without statistical significance, however, when the patients who received more than two distal anastomoses were analyzed, the number in group $G_{1}$ was significantly higher (p-value $<0.0001$ ) (Table 2 ).

Table 2. Number of anastomoses performed

\begin{tabular}{lccc}
\hline & $\mathrm{G}_{1}$ & $\mathrm{G}_{2}$ & $\mathrm{p}$-value \\
\hline Mean No Anastomoses / Patient & 2.83 & 2.08 & N.S. \\
Distal anastomoses (> 2) & 40 & 14 & $<0.0001$.
\end{tabular}

Among the complications evidenced, only low cardiac output syndrome in 6 patients of group $G_{1}$ was significant, whilst there were no such events in Group $\mathrm{G}_{2}$ (p-value $=$ 0.0267 ), even so there were no cases of AMI in the peroperative period.

The incidence of strokes was low, affecting just two patients in group $G_{1}$ and none in group $G_{2}$. Also there were no cases of the appearance or worsening of renal insufficiency or AMI in the post-operative period of the two groups. Respiratory insufficiency occurred in 8 patients, four in each group.

The hospital stay of the two groups ranged from 4 to 77 days, with a mean stay of 21.7 days ( 8 to 77 days for group $\mathrm{G}_{1}$ and 4 to 17 days for group $\mathrm{G}_{2}$ ), data which when analyzed using the chi-squared test did not demonstrate any significant difference. And finally, in relation to hospital 
mortality, $92 \%$ from group $\mathrm{G}_{1}$ and $96 \%$ from group $\mathrm{G}_{2}$ survived, with no statistical difference between the two groups according to the chi-squared test (Table 3 ).

Table 3. Results

\begin{tabular}{lccc}
\hline Parameter & $\mathrm{G}_{1}(\%)$ & $\mathrm{G}_{2}(\%)$ & $\mathrm{p}$-value \\
\hline Stroke & $2(4)$ & $0(0)$ & N.S. \\
Renal insufficiency & $0(0)$ & $0(0)$ & N.S. \\
Respiratory insufficiency & $2(4)$ & $2(4)$ & N.S. \\
Acute myocardial insufficiency & $0(0)$ & $0(0)$ & N.S. \\
Low output & $6(12)$ & $0(0)$ & 0.0267 \\
Survival after 30 days & $46(92)$ & $48(96)$ & N.S. \\
Hospitalization (days) & $21.7(8$ to 77$)$ & $11.7(4$ to 17) & N.S. \\
\hline
\end{tabular}

\section{COMMENTS}

DEMERS \& CARTIER [7] analyzed 98 over 70-year-old patients operated on without the use of CPB between 1996 and 1999. They demonstrated that MR in elderly patients is associated with an increase in the rate of post-operative morbid-mortality and that it is potentially useful to avoid CPB. In this study, the patients operated on without CPB were older, although there was no statistical significance in respect to gender, infarction, neurological events and mortality in the per-operative period. There were differences in the number of grafts performed in each group, incidence of post-operative atrial fibrillation and the necessity of transfusion which were lower in the group in which CPB was not employed. They concluded that in aged patients suffering from multiple artery injuries, off-pump MR represents an alternative technique of treatment.

KILO et al. [8] analyzing 44 over 75 -year-old patients matched in respect to post-operative risk factors, verified that operative mortality was greater in a group that underwent surgery using $\mathrm{CPB}(15.9 \%$ versus $4.5 \%$; -value $=0.0226$ ) when compared with a group that underwent offpump MR. The former group also received a greater number of grafts per patient and performed complete MR in a greater number of cases $(100 \%$ versus $63.6 \%$; $p$-value $=0.001)$. From this they concluded that for incomplete target vessel revascularization in high-risk patients, the off-pump technique seems a promising option.

RICCI et al. [9], analyzing the potential benefits of offpump MR in 269 patients in their 80s operated on between January 1995 and May 1999, concluded that elderly patients submitted to off-pump MR presented with rates of strokes significantly lower than those operated on with the use of CPB. In the analysis, they confirmed a greater tendency of mortality in the off-pump group.

HART [10], in a retrospective study analyzing 140 over 70-year-old patients, suggested that off-pump MR may become the choice procedure for aged patients.

HIROSE et al. [11], comparing patients operated on between 1st July 1991 and 30th September 2001, reported a greater mean number of grafts (3.7 versus 3.3 - p-value $<0.001$ ) in patients operated on using $\mathrm{CPB}$, without significant difference in the hospital mortality rates. They concluded that in MR patients involving multiple arteries, recovery is faster without the use of CPB but the rates of complications in the early follow-up period are similar in the two groups.

CZERNY et al. [12] concluded that off-pump MR is effective for complete revascularization in the majority of selected low-risk patients. However, the rate of incomplete revascularization in this cohort is high, demonstrating the necessity of further studies to verify the facts.

Our study shows that the groups of patients bring small statistically significant differences such as a greater number of smokers (16 versus 6; p-value 0.0283$)$ and a greater percentage of patients with dyslipidemia $(64 \%$ versus $32 \%$; $p$-value $=0.0025)$ in $G_{1}$. These facts do not seem to have a great influence on the results, mainly because $\mathrm{G}_{2}$ is the group that presents with the highest percentage of patients with more than 2 involved coronary arteries, despite there not being statistical significance. An apparently controversial fact is that the group operated on with CPB presented with a number of patients with more than two distal anastomoses greater than the off-pump group (Table 2). This mainly occurred because with patients operated on using CPB, the easier approach can encourage the surgeon to perform anastomoses on more than one branch when the obstruction occurs on the principal branch, (e.g. - revascularization of two important marginal branches, when the obstruction appears in the circumflex artery).

We did not evidence a greater incidence of morbidmortality in the group that utilized $\mathrm{CPB}$, only the postoperative low output syndrome was significant, which can be explained by the bad myocardial protection, as apparently both groups were similar in respect to operative risk factors. This fact seems to show that despite that a more complete MR using CPB may be possible, this also brings a longer operative time and greater aggression to the myocardium. Apart from the other possible deleterious effects of CPB (already well published) in this method, there is always the necessity of aortic clamping and anoxic cardiac arrest, and the utilization of several possible methods of myocardial protection.

The hospital mortality rate (the first 30 days) was similar in the two groups, and the time of hospitalization, which did not present with statistical difference, demonstrated a tendency of a longer hospital stay for patients of $\mathrm{G}_{1}$. This occurrence can be explained by the fact that this group had a greater incidence of low output syndrome, which, as has already been stated, may be due to bad myocardial protection. 


\section{CONCLUSIONS}

Based on the information obtained from the analysis of the data, we can confirm that in our cohort there was no significant difference between the techniques employed for MR in aged patients. The data suggest that, it is possible achieve complete MR when CPB is not employed as long as a lower number of distal anastomoses per patient are performed. The data also show that despite of achieving complete MR, there was a greater morbidity (a greater incidence of post-operative low output syndrome) in $G_{1}$, suggesting the necessity of complementary studies to define which method is the best for the elderly patients.

\section{BIBLIOGRAPHIC REFERENCES}

1. Gibbon JH Jr. Application of a mechanical heart and lung apparatus to cardiac surgery. Minn Med 1954; 37:171-85.

2. Sones FM Jr, Shirey EK. Cinecoronary arteriography. Mod Concepts Cardiovasc Dis 1962; 31:735-8.

3. Effler DB, Groves LK, Sones FM Jr, Shirey EK. Endarterectomy in the treatment of coronary artery disease. $\mathrm{J}$ Thorac Cardiovasc Surg 1964; 47:98-108.

4. Senning A. Strip grafting in coronary arteries: report of a case. J Thorac Cardiovasc Surg 1961; 41:542-9.
5. Kolesov VI, Potashov LV. Operations on the coronary arteries. Exp Anaesth 1965; 10: 3-7.

6. Favaloro RG. Saphenous vein graft in the surgical treatment of coronary artery disease. Operative technique. J Thorac Cardiovasc Surg. 1969; 58:178-85.

7. Demers P, Cartier R. Multivessel off-pump coronary artery bypass surgery in the elderly. Eur J Cardiothorac Surg 2001; 20:908-12.

8. Kilo J, Baumer H, Czerny M, Hiesmayr MJ, Ploner M, Wolner E et al. Target vessel revascularization without cardiopulmonary bypass in elderly high-risk patients. Ann Thorac Surg 2001; 71:537-42.

9. Ricci M, Karamanoukian HL, Abraham R, Von Fricken K, D'Ancona G, Choi S et al. Stroke in octogenarians undergoing coronary artery surgery with and without cardiopulmonary bypass. Ann Thorac Surg 2000;69:1471-5.

10. Hart JC. A review of 140 Octopus off-pump bypass patients over the age of seventy: procedure of choice? Heart Surg Forum 2001;4(Suppl 1):S24-9.

11. Hirose H, Amano A, Takahashi A. Off-pump coronary artery bypass grafting for patients with three-vessel disease. Surgery 2002;132:57-65.

12. Czerny M, Baumer H, Kilo J, Zuckermann A, Grubhofer G, Chevtchik $\mathrm{O}$ et al. Complete revascularization in coronary artery bypass grafting with and without cardiopulmonary bypass. Ann Thorac Surg 2001;71:165-9. 